\title{
An in vivo model to study the anti-malaric capacity of plant extracts
}

\author{
Misael Chinchilla', Olga M. Guerrero. Gabriela Abarca, Mariano Barrios y Oscar Castro² \\ I Centro de Investigación en Enfermedades Tropicales (CIET) y Departamento de Parasitología, Facultad de Microbiología, \\ Universidad de Costa Rica, 2060 Costa Rica. \\ Universidad Nacional, Departamento de Química, Heredia 3000, Costa Rica.
}

Receibed 31-VII-1996. Corrected 05-IX-1997. Accepted 15-X-1997

\begin{abstract}
An in vivo model to study the antimalaric effect of plant extracts is described. White mice (25-30g body weight) are treated subcutaneously with $0.6 \mathrm{ml}$ of the diluted extract starting seven days before $P$. berghei infection; treatment continues until death or for 30 days. Simultaneously $0.2 \mathrm{ml}$ of the extract are applied per os starting three days before infection. In a test of the model, treated and non-treated animals differed in body weight, survival time, haematocrite, parasitemia development, and spleen or liver weight of recent dead or killed mice.
\end{abstract}

Key words: Malaria, Plasmodium berghei, treatment, plants.

Malaria, one of the most important human diseases, is responsible for thousands of deaths each year, and has been included among the WHO's control priority infections (Anonymous 1990). Although epidemiology and prevention has been improved to attack such parasitosis, human treatment is still neccesary all over world.

Quinin, an active product extracted from Cinchona (Rubiaceae), was probably first important drug used in malarial treatment (Belding 1942) before synthetic drugs. In recent years, natural products are of interest again because drug resistance increased (White \& Nostem 1993). These include Qinghaosu and other artemisin derivates (Klayman 1985, Shmuklarsky et al. 1993) with an excellent antimalaric power. The in vitro assays are commonly used for convenience (Le Bras \& Deloron 1983, Basco \& Le Bras 1993), but they lack the physiological aspects that make in vivo studies so desirable. Long methods refer to Plasmodium falciparum or Plasmodium vivax parasites and therefore their rules may not apply to a murine model. This paper describes an in vivo murine method that provides a more reliable indication of plant extract effects.

\section{MATERIALS AND METHODS}

Animals: White mice (NGP strain) of 25-30 g body weight were used either for treatment experiments or for strain maintenance.

Parasites and inocula: We used Plasmodium berghei (NK strain) from the Department of Health Education and Welfare, National Institutes of Health, Bethesda, Maryland, kept in our laboratory by weekly passage in white mice. Inocula for the different experiments have been prepared according to the next scheme.

Blood smears from 6-10 day infected animals are stained by the Giemsa technique, infected red cells are counted six times and the mean is used; erythrocyte total number is established by the usual count in haemocytometer (mean of six counts).From these two digits the number of parasitized cells per $\mathrm{ml}$ is calculated. Corresponding dilutions for wanted inocula 
(usually $10^{5}$ or $10^{6}$ per animal), are prepared for each experiment. As soon as possible, subcutaneous infection is performed in all the cases, inoculating the animals at random.

Plant extract preparation: Plant crude extracts were prepared as previously reported (Castro et al. 1996). To prepare the inocula for treatment of malaria infected mice, approximately $0.1 \mathrm{~g}$ of the corresponding plant crude extract is diluted 1: 25 or 1: 100 in $0.85 \%$ saline solution. Some other dilutions are prepared according to each experiment.

Toxicity tests: To avoid toxic action masking on any curative effect, groups of five animals are inoculated s.c. with several dilutions of each extract. All mice are studied by the general aspect, body weight variations, haematocrite and survival time.

Treatment design: Animals are inoculated s.c. and daily with $0.6 \mathrm{ml}$ of the adequate extract dilution, starting three days before malaria infection and keeping that treatment until death or for 30 days. Additionally we apply $0.2 \mathrm{ml}$ per os, besides the s.c. treatment.

Parameters to follow the infection: To determine the differences between controls (nontreated animals) and plant extract testing mice, the following aspects are studied.

Survival time: Dead animals are counted 2-3 times daily. Mice in very bad conditions at day's end are recorded as dead.

Haematocrite: Blood from the animal tail is collected in heparine microhaematocrite tubes and centrifugued at 5000 RPM. Data are recorded twice a week and the average of five animals is determined for each group.

Parasitemia follow up: Blood smears from each mice (all groups) are stained twice a week and number of infected red cells are counted. Six counts of 85 to 160 cells by smear are performed and means are recorded for each animal and then for each group.

Body and spleen or liver weight: Recently dead mice, and mice killed because they were in poor conditions are weighted (as spleens and livers).In addition all the animals are weighted previously to the infection and then twice a week.

\section{RESULTS}

Control mice survived less than treatedanimals (Table 1). In all the animals the hematocrite starts at the the normal mean (Wechsler 1983), but decreases with infection time and there are differences between controls and treated mice that can be easily monitored (Fig. 1). On the other hand parasitemia increases with infection time. Non-treated animals reach the higher number of infected red cells and usually die earlier than those in which some of plant extracts appear to exert any curative effect; lower and higher parasitemias and other details are shown in Table 2, and weights in Table 3. Moreover treated animals showed a lower body weight pattern as compared with non-treated animals. With time mice became motionless, with bristled hair and difficult breathing, specially in the non-treated individuals.

\section{DISCUSSION}

The treatment design that we describehere has demonstrated to be the satisfactory enough to detect, not only any curative effect of the plant extract, but preventive action also. Later it is possible to determine each effect separately.

$P$. berghe $i$ in mice is a good model to compare with human malaria (Box et al. 1954, Peters 1974): animals suffer anaemia because of red cell destruction, either by parasite multiplication or by spleen reticuloendotelial cell action. Absence of erythrocytes cause respiratory insufficiency 
that added to other problems, causes death. The presence of many abnormal red cells stimulates the spleentoproduce manyphagocytes. Therefore remarkable hyperplasia is evidenced by splenomegaly and occasionally hepatomegaly. Therefore, although in human models only parasitemia and survival time are considered, we believe that haematocrite analysis, survival time and spleen weight are necessary to follow disease evolution. Besides that, of course, parasitaemia curves give the information on parasite development. It is necessary to do several counts in the stained smears to avoid errors causes by incorrect selection of area (Chinchilla \& Frenkel 1984, Reyes \& Chinchilla 1987). Body weight is also important (Guerrero et al. 1994, Chinchilla et al. 1993). The parameters presented here are enough to establish any differences between treated and non-treated infected animals.

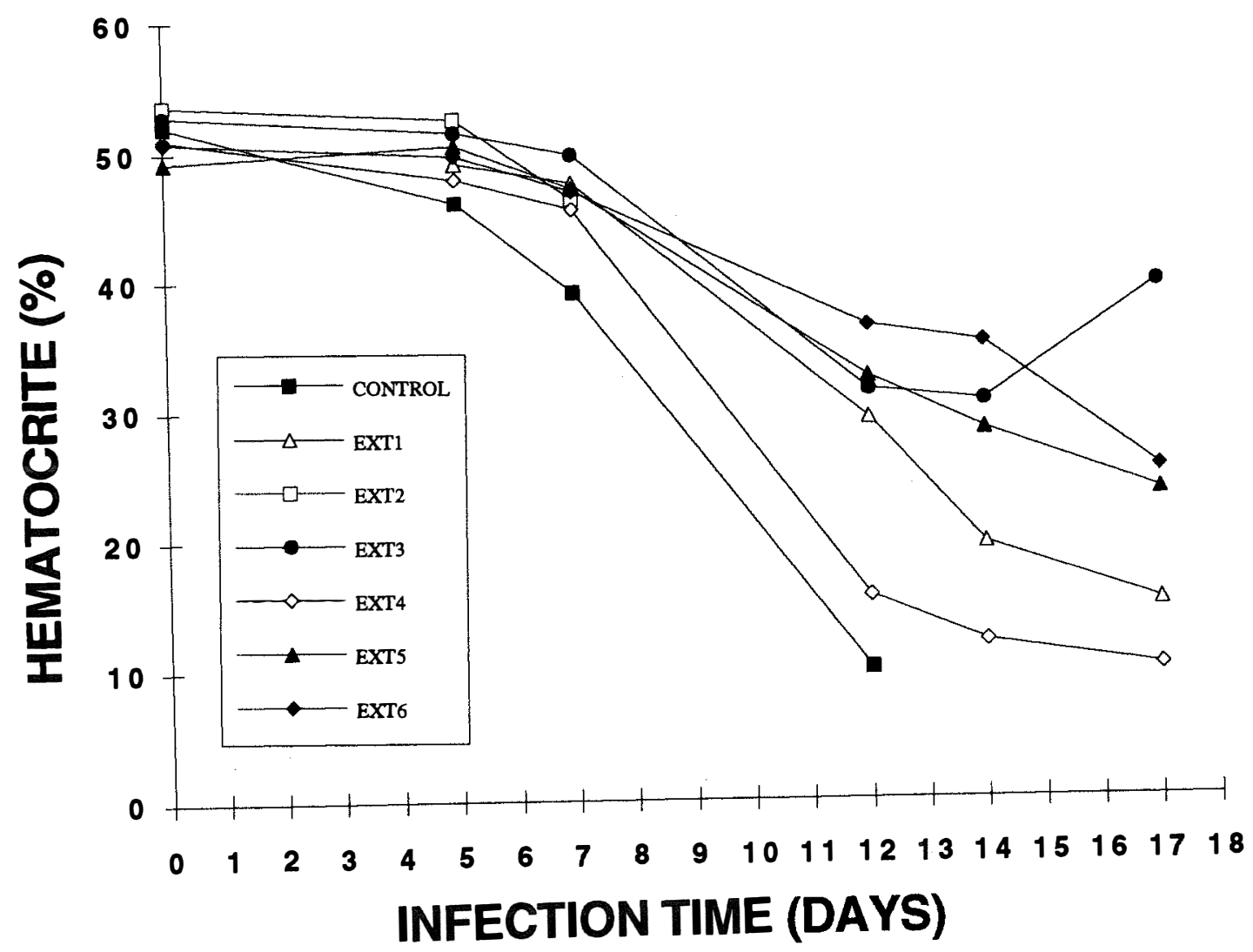

Fig. 1. Hematocrite versus infection time. 


\section{TABLE 1}

Survival time of treated and non-treated animals infecred with P. berghei.

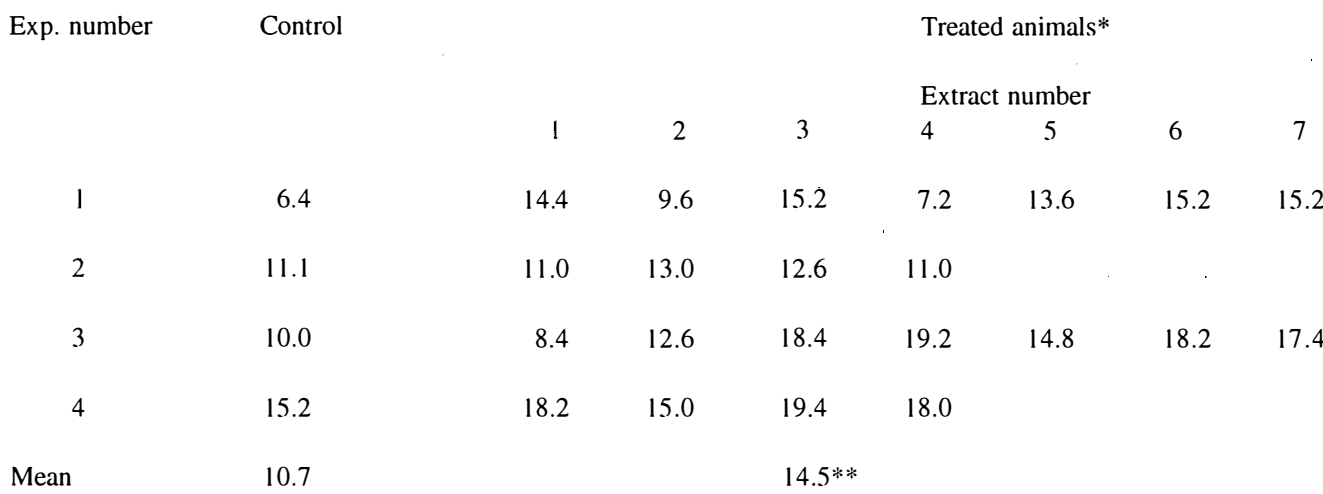

* Five animals per extract

** Refers to the mean of survival time for all the extracts.

TABLE 2

Parasitemia of treated and non-treated animal infected with $\mathrm{P}$. berghei.

Day after infection

\begin{tabular}{|c|c|c|c|c|c|c|c|}
\hline $\begin{array}{l}\text { Group } \\
\text { (extracts) }\end{array}$ & 0 & 5 & 7 & 12 & 14 & 16 & 18 \\
\hline Control & 0.0 & 0.0 & $3.5^{*}$ & 51.4 & - & - & - \\
\hline Ext 1 & 0.0 & 0.0 & 0.5 & 30.1 & 20.0 & 28.0 & - \\
\hline Ext 2 & 0.0 & 0.3 & 0.4 & - - & - - & & \\
\hline Ext 3 & 0.0 & 0.06 & 2.0 & 22.2 & 17.9 & 0.0 & 0.0 \\
\hline Ext 4 & 0.0 & 0.06 & 10.2 & - & - & - & - \\
\hline Ext 5 & 0.0 & 0.04 & 6.4 & 34.9 & 32.4 & $38.0-$ & \\
\hline Ext 6 & 0.0 & 0.2 & 1.9 & 14.7 & 18.9 & $12.2-$ & \\
\hline Ext 7 & 0.0 & 0.2 & 1.9 & 14.7 & 18.9 & 12.2 & \\
\hline
\end{tabular}

* Percentaje of infected red cells in five mice. 
TABLE 3

Spleen ${ }^{(S)}$ or liver ${ }^{+1.2}$ weight/mouse body weight factor of treated and non treated animals.

$\begin{array}{lll}\text { Extracts } & \mathrm{S} / \mathrm{T}^{*} & \mathrm{~L} / \mathrm{T}^{*} \\ \text { Controls } & 1.84 & 9.14 \\ \text { Ext 1 } & 1.43 & 8.55 \\ \text { Ext 2 } & 1.21 & 8.24 \\ \text { Ext 3 } & 0.62 & 7.81 \\ \text { Ext } 4 & 1.04 & 10.0 \\ \text { Ext 5 } & 1.48 & 10.31 \\ \text { Ext 6 } & 0.84 & 9.78\end{array}$

* Data X

\section{ACKNOWLEDGMENTS}

This work was financed by Vicerrectoría de Investigación, University of Costa Rica and NationalInstitute of Biodiversity (INBIO) project: "Chemical and Biological Prospectives", using funds of the MacArthur Foundation. We thank Edwin Valenciano and Eddy Camacho for animal care.

\section{REFERENCES}

Anonymous. 1990 World Report on Tropical Diseases. WHO Features 139: 1-12.

Basco, L.K. \& J. Le Bras. 1993. In vitro activity of artemising derivatesagainst african isolates and clones of Plasmodium falciparum. Am.J.Trop.Med.Hyg. 49: 301-307.

Belding, D.L. 1942. Textbook of Clinical Parasitology. D. Appleton, New York, 888p.

Box, D.E., W. Gingrich \& B. Celaya. 1954. Standarization of a curative test with Plasmodium berghei in white mice. J. Infect. Dis. 94: 78-83.
Castro, O., M. Barrios, M. Chinchilla \& O. Guerrero. 1996. Evaluation química y biológica del efecto de extractos de plantas contra Plasmodium berghei. Rev. Biol. Trop. 44: 361-367.

Chinchilla, M. \& J.K. Frenkel. 1984. Specific mediation of cellular immunity to Toxoplasma gondii in somatic cells of mice. Infect. Immun. 46: 862-866.

Chinchilla, M., O.M. Guerrero, G. Catarinella \& L. Reyes. 1993. Natural and induced blood dissemination of Toxoplasma gondii: experimental model in white mice and hamsters. Rev. Biol. Trop. 41: 197-202.

Duy Sy, N., D. Boi Hoan, D.N. Phuong Dung, N. Van Houong, L.N. Binh, M. Van Son \& S.R. Meshnick. 1993. Treatment of malaria in Vietnan with oral artemisinin. Am. J. Trop. Med. Hyg. 48: 398-402.

Guerrero,O.M., M. Chinchilla, G. Catarinella, A. Castro \& E. Abrahams. 1994. Patrón de tránsito intestinal de los ooquistes de Toxoplasma gondii en rata, ratón y hamsters. Parasitol. Día 18: 71-76.

Klayman, D.L. 1985. Qinghaosu (artemisin): an antimalarial drug from China. Science. 228: 1049-55. Le Bras, J., P. Deloron. 1983. In vitro study of drug sensitivity of Plasmodium falciparum: An evaluation of a new semimicrotest. Am. J. trop. Med. Hyg. 32: 447-451.

Peters, W. 1974. Recent advancesin antimalarial chemotherapy and drug resistance. Adv. Parasitol. 12: 69-113.

Reyes, L. \& M. Chinchilla. 1987. Growth inhibition of Trypanosoma cruzi in cultured murine myocardial cells mediated by a specifically induced lymphokine. Infect. Immun. 55: 1513-1516.

Shmuklarsky, M.J., D.L. Klayman, W.K. Milhous, D.E. Kyle, N. Rossan, Jr, A.L. Ager, D.B.Tang, M.H. Heiffer, C.J. Canfield \& B.G. Schuster. 1993. Comparison of 3artemether and 3 arteether against malaria parasites in vitro. Am. J. trop. Med. Hyg. 48: 377-384.

Wechsler, S.J, 1983. Blood collection techniques and normal values for ferrets, rabbits and rodents. VM/SAC. 78: 713717.

White, N.J. \& E. Nosten. 1993. Advances in chemotherapy and prophylaxis of malaria. Inf. Dis. 6: 323-330. 